\title{
Abundance and distribution of planktonic Lepeophtheirus salmonis and Caligus elongatus in a fish farming region in the Faroe Islands
}

\author{
G. á Norði ${ }^{1, *}$, K. Simonsen ${ }^{1}$, E. Danielsen ${ }^{1}$, K. Eliasen ${ }^{1}$, A. Mols-Mortensen ${ }^{1}$, \\ D. H. Christiansen ${ }^{2}$, P. Steingrund ${ }^{3}$, M. Galbraith ${ }^{4}$, Ø. Patursson ${ }^{1}$ \\ ${ }^{1}$ Fiskaaling - Aquaculture Research Station of the Faroes, við Áir, 430 Hvalvík, Faroe Islands \\ ${ }^{2}$ Faroese Food and Veterinary Authority, V. U. Hammershaimbsgøta 11, 100 Tórshavn, Faroe Islands \\ ${ }^{3}$ Faroe Marine Research Institute, Nóatún 1, 100 Tórshavn, Faroe Islands \\ ${ }^{4}$ Fisheries and Oceans Canada, Institute of Ocean Sciences, 9860 West Saanich Road, Sidney, British Columbia W8L 4B2, Canada
}

\begin{abstract}
The abundance of planktonic sea lice in the surface waters of the strait of Sundalagið, Faroe Islands was investigated from November 2013 to June 2014. The strait is $38 \mathrm{~km}$ long and hosts 6 salmon farms with coordinated farming cycles. The spatial distribution of planktonic sea lice for the entire strait was examined in 2 surveys with different wind and hydrographic conditions. Temporal changes were investigated every $2-3$ wk at 3 set stations throughout the study. The spatial distribution of Lepeophtheirus salmonis copepodids was clearly influenced by the actual wind direction, as the copepodids were found where winds pushed surface waters towards the shore. The same spatial pattern was not found for Caligus elongatus copepodids. This might be related to a different vertical migration pattern. The abundance of $C$. elongatus was seasonal. It was the dominant planktonic sea louse during winter, with a mean abundance of $0.34 \pm 0.13$ ind. $\mathrm{m}^{-3}$, and was virtually absent during summer. Lepeophtheirus salmonis was present throughout the study, except during the last survey when the coordinated farming sites lay fallow. During winter when the warmest seawater was deep in the water column, L. salmonis copepodids were present in $47 \%$ of the samples and nauplii were only observed in $9 \%$. In samples where the highest seawater temperature was at the surface, nauplii prevalence attained a high value of $53 \%$, while copepodid prevalence increased to $60 \%$. These results indicate that nauplii might actively seek the highest possible seawater temperature.
\end{abstract}

KEY WORDS: Lepeophtheirus salmonis $\cdot$ Caligus elongatus $\cdot$ Sea lice $\cdot$ Infectious copepodid · Nauplii · Aquaculture

\section{INTRODUCTION}

Sea lice are ubiquitously associated with salmon farms, and have been rated as the most damaging parasites in the salmon farming industry (Costello 2006). In Faroese fish farming areas, the temperature $\left(6-12^{\circ} \mathrm{C}\right)$ and salinity $(>30)$ are highly suitable for Atlantic salmon Salmo salar L., 1758 farming, as well as for production of sea lice (Johnson \& Albright 1991). Like elsewhere in the Atlantic Ocean (Boxas-

${ }^{*}$ Corresponding author: gunnvor@fiskaaling.fo pen 2006), the 2 most abundant sea lice species on salmon farmed in Faroese waters are the salmonid specialist Lepeophtheirus salmonis (Krøyer, 1837), and the teleost generalist Caligus elongatus (Nordmann, 1832), which has been found on >80 fish species (Kabata 1979).

Both species have 2 planktonic nauplii stages prior to the infective copepodid stage. The duration of the nauplii stages is temperature dependent, with shorter development time at higher temperatures

(C) The authors 2015. Open Access under Creative Commons by Attribution Licence. Use, distribution and reproduction are unrestricted. Authors and original publication must be credited. 
(Pike et al. 1993, Stien et al. 2005). The limited endogenous energy supply defines the period in which the infective copepodid has to find a suitable host, where the ectoparasitic life cycle stage is initiated (Piasecki \& MacKinnon 1995, Hamre et al. 2013).

Lepeophtheirus salmonis has been investigated to a larger extent than other sea lice species (Boxaspen 2006). The planktonic stages migrate vertically in response to environmental stimuli-e.g. swimming towards light (Heuch et al. 1995) and avoidance of freshwater (Bricknell et al. 2006). To our knowledge, sensing of temperature has not been observed in laboratory experiments, but model simulations have shown that it would be beneficial for nauplii to seek the highest possible temperature vertically, as this would reduce the duration of nauplii stages by up to $1 \mathrm{~d}$, hence decreasing the risk of mortality (Johnsen et al. 2014).

Copepodids respond to chemical and mechanical stimuli with burst swimming, which plays a role in host finding (Gravil 1996, Pike \& Wadsworth 1999, Mordue \& Brikett 2009). However, when transported over distances, sea lice are thought to drift passively with the currents (Boxaspen 2006), and can easily be transported several kilometres away from their origin (Salama \& Rabe 2013, Asplin et al. 2014).

In coastal environments, the planktonic stages of $L$. salmonis are most abundant in the upper few meters of the water column (Heuch et al. 1995, Hevrøy et al. 2003, McKibben \& Hay 2004, Penston et al. 2004). Copepodids tend to aggregate in shallow estuarine areas, which are ideal locations for intercepting migratory salmonids (Pike \& Wadsworth 1999, McKibben \& Hay 2004, Penston et al. 2004, Costello 2006). In fact, the highest densities of copepodids have been found by wading and towing plankton nets along the shore (McKibben \& Hay 2004, Penston et al. 2004). Copepodids are the main infective life cycle stage of the species, but infection by preadults and adults have also been observed in the field (Pert et al. 2014).

Caligus elongatus adults readily transfer between hosts and species (Øines et al. 2006) and have been found on several species which are commercially fished in Faroese waters, including cod (Gadus morhua), haddock (Melanogrammus aeglefinus), saithe (Pollachius virens), mackerel (Scomber scombrus), and herring (Clupea harengus) (Neilson et al. 1987, MacKenzie \& Morrison 1989, Øines et al. 2006, Heuch et al. 2007). All of these fish species inhabit the coastal zone to various degrees, and aggregate around fish farms (Dempster et al. 2009).

Infestation of farmed fish by $C$. elongatus is often seasonal. In Scotland, the epidemiology of $C$. elonga- tus on farmed fish shows increased infection from June to late September (Revie et al. 2002, McKenzie et al. 2004). In the central and northern parts of Norway, high $C$. elongatus abundance on farmed fish frequently occurs in autumn (Øines et al. 2006). Infections have been assumed to be connected to passing schools of pollock, saithe or herring. In British Columbia, epizootics of C. clemensi infestations on wild and farmed salmonids have occurred as migrating Pacific herring enter the area during winter (Morton et al. 2008, Beamish et al. 2009).

A study of wild fish on the coast of Norway showed that $C$. elongatus was present on 27 of 52 species caught, several of which had higher infestation during autumn (Heuch et al. 2007). This observation demonstrates the difficulty in determining the causal mechanism or species in the seasonal infestation pattern that is often observed on farmed fish, as correlations between species are likely to be due to derived rather than causal reasons.

The present study investigated the seasonal and spatial abundance of planktonic $L$. salmonis and $C$. elongatus in the coordinated fish farming region of Sundalagið, Faroe Islands. The study also included simultaneous investigation of winds and hydrography, and differentiated between sea louse species both in the copepodid and nauplii stages. This approach enabled investigations on the seasonal and farming dependent abundance of the 2 species, as well as the influence of hydrography on distribution. This study provides the first information on the abundance and distribution of planktonic sea lice in Faroese waters.

\section{MATERIALS AND METHODS}

\section{Study area}

The study was conducted in Sundalagið, which is a $\sim 38 \mathrm{~km}$ long strait between the 2 largest islands in the Faroes. Sundalagið consists of 2 main basins separated by a narrow $(150 \mathrm{~m})$ and shallow $(4 \mathrm{~m})$ sill (Fig. 1). The northern basin is narrow $(\sim 1 \mathrm{~km}), 11 \mathrm{~km}$ long, is separated from the open ocean by a $10 \mathrm{~m}$ deep sill, and has a maximum bottom depth of $60 \mathrm{~m}$. The southern basin is wider and deeper than the northern basin and has 3 adjacent fjords. Its maximum depth is $80 \mathrm{~m}$ and the sill that restricts the strait southward into a deeper and more energetic strait is $40 \mathrm{~m}$ deep (Fig. 1).

In the southern basin, the tidal influence is small as this area is part of a semi-amphidromy in the otherwise dominating semi-diurnal tides (Simonsen \& Nic- 


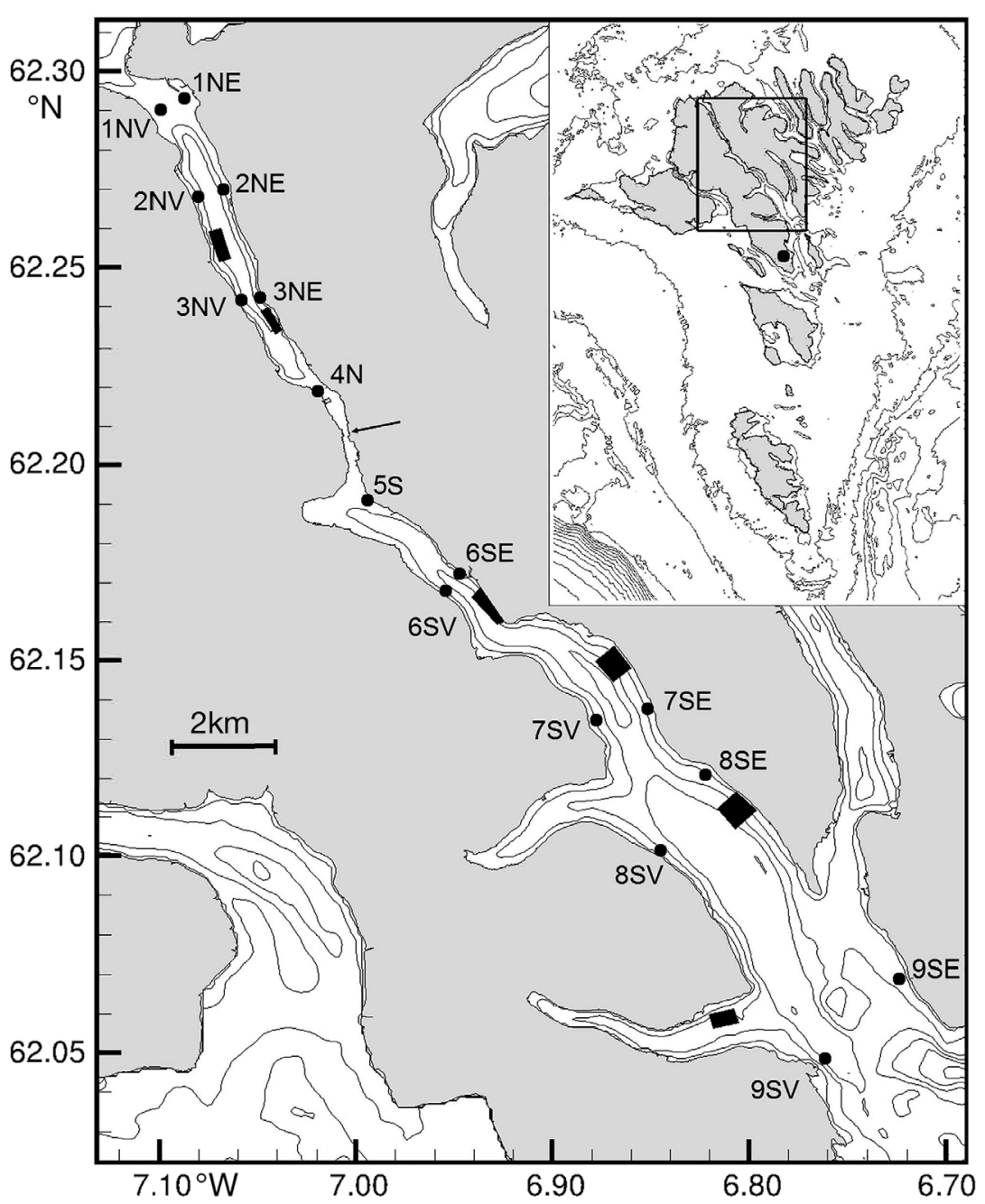

Fig. 1. Sampling stations $(\bullet)$ and salmon farming areas (black blocks). The arrow points out the narrow and shallow sill that divides Sundalagio into 2 main basins. N, S, E, V: stations located in the northern and southern basins, and in the eastern and western shores, respectively; isobaths for every $20 \mathrm{~m}$ depth; inset: location of the study area in relation to Faroe Islands (with $50 \mathrm{~m}$ isobaths); (• in inset): the weather station Glyvursnes lasen 2011), while the tidal range may exceed $2 \mathrm{~m}$ in the northern basin. This creates quite strong currents above the shallow sill between the 2 basins; otherwise, circulation is generally wind and freshwater driven. Seawater from the Faroe shelf enters Sundalagið at both ends of the strait. The relatively saline water mainly enters the strait at depth in the water column, and is overlaid by less saline water brought in by freshwater runoff particularly in the northern basin. This leads to weak and variable stratification of the surface waters.

Due to the highly variable weather conditions, with wind and precipitation changing within short time scales, hydrodynamics driven by wind and freshwater are also highly changeable (Gaard et al. 2011).
However, circulation in the northern basin is more affected by tides than that in the southern basin.

In the period 2010 to 2014, there were 6 active fish farms in Sundalagið and adjacent fjords (Fig. 1), with coordinated farming and production cycles of $18 \mathrm{mo}$, followed by a fallowing period of at least 2 mo as required by legislation. However, in order to organize the coordination between the farms, the fallow period was substantially longer at most farms.

At the onset of the study, the farms were at the end of the grow-out period. In the southern basin, harvesting commenced in October 2013 and was finalized by April 2014. From this date, there were no farmed fish in the southern basin. In the northern basin, harvesting commenced in March 2014, and was finalized on June 10, 2014; consequently, there were no farmed fish in Sundalagið during the last survey. The number of adult female Lepeophtheirus salmonis during the study was constantly $<2$ per fish, which is the legislated maximum allowable abundance.

\section{Sampling}

The sampling period was from November 18, 2013 to June 23, 2014. Two sampling protocols were used-one to focus on temporal changes and the other to address spatial changes.

During winter, the relatively high seawater temperature $\left(6^{\circ} \mathrm{C}\right)$ is suitable for sea lice production (Stien et al. 2005); combined with the absence of primary production (Gaard et al. 2011), this made it practical to sample as many as 16 stations (Fig. 1) and investigate the entire sample content with a stereomicroscope within $1 \mathrm{wk}$ of each survey. The comprehensive sampling effort made it possible to obtain an overview of the spatial distribution of planktonic sea lice in the investigated area. The 16 stations were located along both sides of the strait and 2 surveys were conducted.

Temporal changes in the abundance of planktonic sea lice were investigated at 3 stations every 2 to $3 \mathrm{wk}$. Two of the time series stations (Stns 3NE and $4 \mathrm{~N})$ were in the northern basin where 2 fish farms were located (Fig. 1). Stn 3NE was located $\sim 600 \mathrm{~m}$ 
northwest of a fish farm, while Stn $4 \mathrm{~N}$ was $2.3 \mathrm{~km}$ southeast of the same farm (Fig. 1). Surface currents at the farm were predominantly in a NW direction (Ø. Patursson unpubl. data). The third time series station (Stn 5S) was located in the southern basin. The distance to the nearest fish farm was $\sim 5 \mathrm{~km}$. At that particular farm, the last fish were harvested in late February 2014.

Samples were taken using a $150 \mu \mathrm{m}$ mesh size plankton net, with a mouth diameter of $50 \mathrm{~cm}$ and a length of $1.5 \mathrm{~m}$. To keep the net at a constant depth and the mouth perpendicular to the surface, floats and weights were mounted on it. The uppermost part of the mouth was at $\sim 0.25 \mathrm{~m}$ below the surface. The plankton net was towed from a $7.92 \mathrm{~m}$ boat. Tows started as close to the shore as possible (distance to shore $=10$ to $30 \mathrm{~m}$ ), and were taken seawards for 200 $\pm 21 \mathrm{~m}$, with a constant speed of 1.5 knots. At Stn $4 \mathrm{~N}$ which is in the narrow passage in the sound (Fig. 1), tows were taken from shore to shore across the sound ( $240 \mathrm{~m})$. The towing distance was monitored using a GPS (Garmin ${ }^{\circledR}$ ). The towing distance and mouth area of the plankton net were used to calculate the volume of filtered seawater. In May, the volume of filtered seawater was affected by some clogging of the net due to the abundance of phytoplankton in the seawater. For the rest of the year, the samples showed no signs of clogging.

Vertical profiles of temperature and salinity were recorded using a CTD (Sea-Bird Electronics, SBE 25plus) at the offshore end of each tow, except for Stn $4 \mathrm{~N}$, where the profile was taken at the midpoint of the transect. The instrument stored 8 scans s $^{-1}$, and was lowered by hand at a speed of $\sim 0.75 \mathrm{~m} \mathrm{~s}^{-1}$. The data were low-pass filtered and obvious spikes were removed before averaging data into $1 \mathrm{~m}$ bins.

Meteorological observations were obtained at a weather station in Glyvursnes (Fig. 1). This weather station is representative of general wind directions in the Faroe Islands, as the influence of local topography is limited. The station is operated by Landsverk (the local road and harbour authorities) and the data was acquired from their online service (www.landsverk.fo). Records of 10 min mean values of wind speed and direction were used.

\section{Identification}

Samples were preserved in ethanol (99.9\%) and counted within $1 \mathrm{wk}$ of sampling. The entire content was analyzed using a stereomicroscope, and the nauplii and copepodids were identified by their mor- phometrics and pigmentation pattern and colour (Schram 2004; L. salmonis have black and brown pigmens while the pigments in $C$. elongatus are red. Reference was also made to nauplii and copepodids from L. salmonis and Caligus elongatus egg strings hatched in the laboratory (Danielsen 2013) to facilitate identification of the 2 species in mixed field samples. Except for a few specimens $(<1 \%)$, all of the sea lice nauplii were identified to species level. The nauplii that were not identified to species had washed out pigmentation.

\section{Real-time PCR}

For specific identification of $L$. salmonis and $C$. elongatus, a duplex real-time PCR assay was used. DNA was extracted from individual sea lice using the DNeasy mini kit or QIAsymphony DNA kit (Qiagen) following manufacturer recommendations. Duplex real-time PCR was performed using the QuantiTect Probe $^{\mathrm{TM}}$ kit (Qiagen), including L. salmonis and C. elongatus primers $(1 \mu \mathrm{M})$ and TaqMan® ${ }^{\circledR}$ MB probes (200 nM) as designed by McBeath et al. (2006). Amplification was performed on an ABI 7500 FAST Sequence Detection System (Applied Biosystems), with the following cycling profile: activation of the HotStart Taq polymerase at $95^{\circ} \mathrm{C}$ for $15 \mathrm{~min}$, followed by 30 cycles of $94^{\circ} \mathrm{C}$ for $15 \mathrm{~s}$ and $60^{\circ} \mathrm{C}$ for $1 \mathrm{~min}$.

In order to evaluate the possible presence of sea lice other than L. salmonis and C. elongatus in the plankton, the real-time PCR assay was run on nauplii from 2 of the plankton samples. At the time the nauplii were selected for real-time PCR, no pigmentation was visible; thus, the identity of the analyzed nauplii was unknown. In addition, chalimus stages that were randomly sampled from farmed Atlantic salmon in the Faroes have been analyzed routinely using realtime PCR assay from 2010 to 2014.

Pearson's Chi square tests with Yates' Correction for Continuity (Fowler et al. 1998) were performed, with the null hypothesis that the identification of nauplii by microscopy was consistent with the real-time PCR assay. All statistics were performed with the statistical software package R (www.r-project.org).

\section{Sea lice on farmed fish}

Data on C. elongatus abundance on farmed fish was supplied by Marine Harvest Faroes, which operated 2 of the 6 fish farms in Sundalagið. The data was 


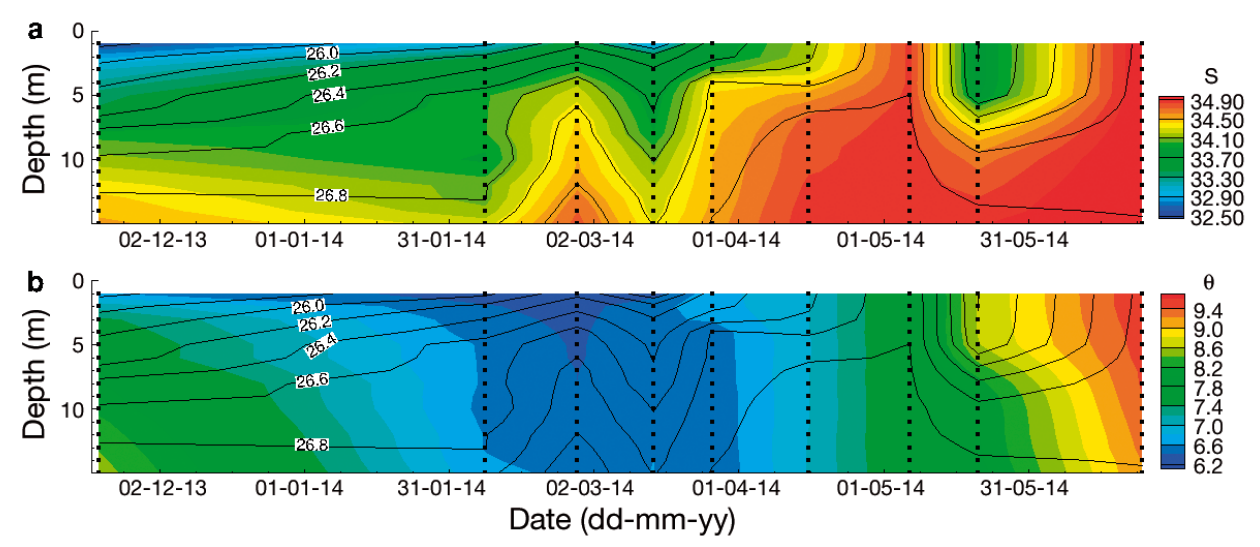

Fig. 2. (a) Salinity, (b) potential temperature $(\theta)$ and potential density ( $\sigma_{\theta}$ i black contours in both plots) in the upper $15 \mathrm{~m}$ at station 3NE from November 18, 2013 to June 23, 2014. Vertical stippled lines denote sampling dates

obtained from the legislated sea lice monitoring programme during the latest 2 production cycles at the farms. Sea lice were counted on 10 fish in each of 4 cages fortnightly, and were grouped into gravids or adults.

\section{RESULTS}

\section{Hydrography and wind}

The water column was stratified on most sampling dates. During winter, the influence of freshwater runoff produced gradients in salinity and density near the surface, while a more homogenous surface layer down to $10 \mathrm{~m}$ depth was observed in late spring (Fig. 2).

Surface waters had the lowest salinity of 32.5 in November, and continued to be relatively fresh until late spring (Fig. 2a). During winter and early spring, the low salinity surface water was colder than the deeper water masses. The minimum sea surface temperature of $6.1^{\circ} \mathrm{C}$ was observed in late February (Fig. 2b). In late March, the surface layer had become slightly warmer than the underlying water, and the general heating continued throughout the rest of the study, reaching the maximum temperature of $9.7^{\circ} \mathrm{C}$ in the last record. This indicates that the highest seawater temperature was at the surface from late March and onwards, as opposed to the winter conditions, when the warmest water was located deeper in the water column (Fig. 2b). Temperature and salinity at $1 \mathrm{~m}$ depth did not differ much among the 3 time series stations ( $3 \mathrm{NE}, 4 \mathrm{~N}$ and $5 \mathrm{~S}$; data not shown).

The influence of winds on the upper water masses was evident when comparing the regional samplings in November 2013 and February 2014. This was most pronounced in the southern basin. In November, there was relatively steady weather with northwest and westerly winds, with mean velocities between 4 and $13 \mathrm{~m} \mathrm{~s}^{-1}$ in the $12 \mathrm{~h}$ prior to the field sampling (Fig. 3). Stratification was deeper and salinity was lower on the east side of the sound compared to the west side in the southern basin (Fig. 4a,b). In the $12 \mathrm{~h}$ prior to the field study in February, winds came from the opposite direction, with velocities between 2 and $11 \mathrm{~m} \mathrm{~s}^{-1}$ (Fig. 3b). Under these circumstances, the southern basin showed deeper stratification and lower salinities on the west side of the sound (Fig. 4c,d). Except for the northernmost station, where a hydropower outlet influenced the salinity particularly at Stn 1NE (Fig. 4), the northern basin showed no pronounced difference in salinity between the east and west side of the sound on either of the sampling dates.

In order to investigate the representativeness of the wind conditions prior to the study, $1 \mathrm{yr}$ wind records (July 1, 2013 to June 30, 2014) were analyzed. Winds from the same directions as those occurring for at least $12 \mathrm{~h}$ prior to the 2 regional samplings were recorded in 11 and $28 \%$ of the time for the November and February samplings, respectively. The higher occurrence of the same conditions as those in February is due to the wider span in the wind direction. In the $12 \mathrm{~h}$ prior to the samplings, the wind speed did not exceed $13 \mathrm{~m} \mathrm{~s}^{-1}$ (Fig. 3), which was the situation in $87 \%$ of the time in the considered year.

\section{Spatial distribution}

Lepeophtheirus salmonis copepodids were found in 7 of the 16 stations in November. The stations were evenly distributed across the northern and southern parts of the sound. However, 5 of the stations where L. salmonis was found were located on the east side of the sound (Table 1). The average density of $L$. 

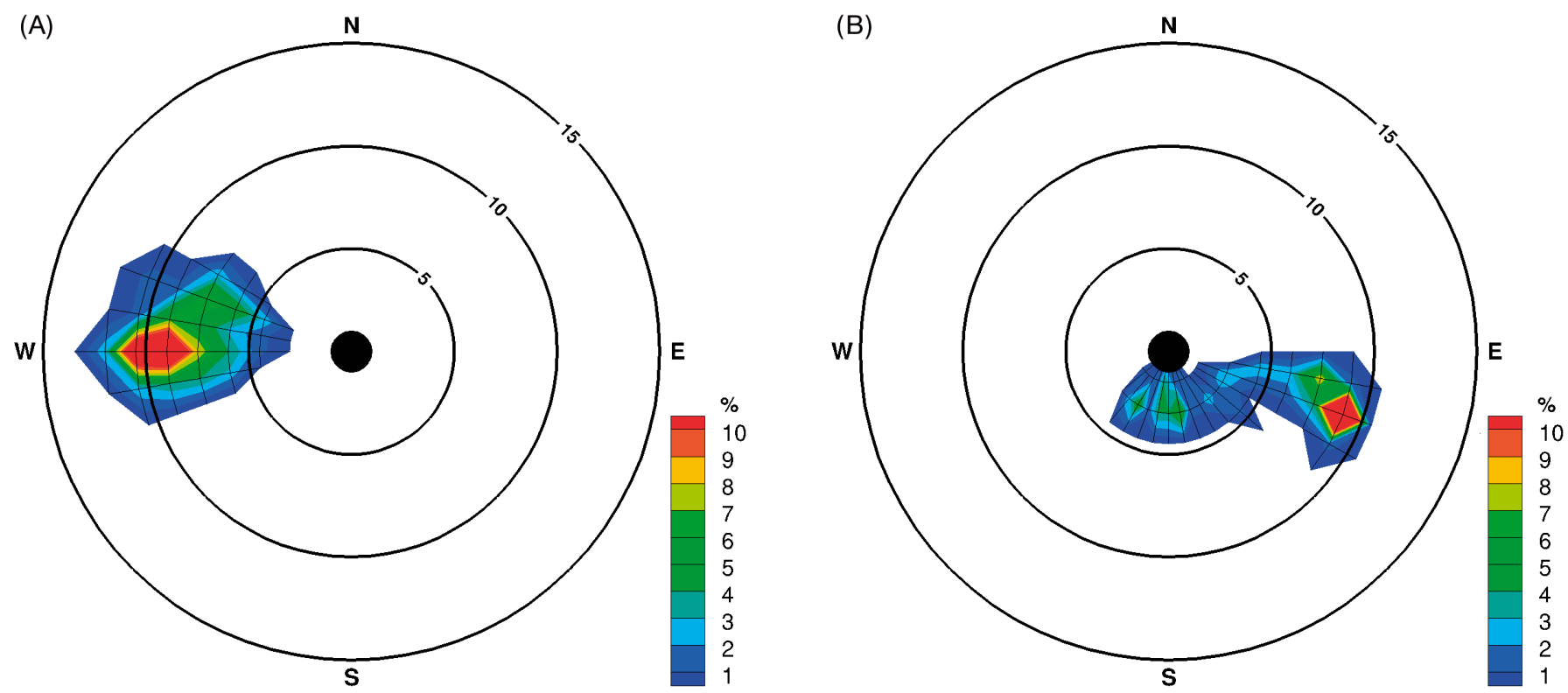

Fig. 3. Frequency plot of wind direction and speed (in $10^{\circ}$ and $1.5 \mathrm{~m} \mathrm{~s}^{-1}$ intervals, respectively) during the $12 \mathrm{~h}$ period prior to the spatial surveys in (A) November 2013 and (B) February 2014
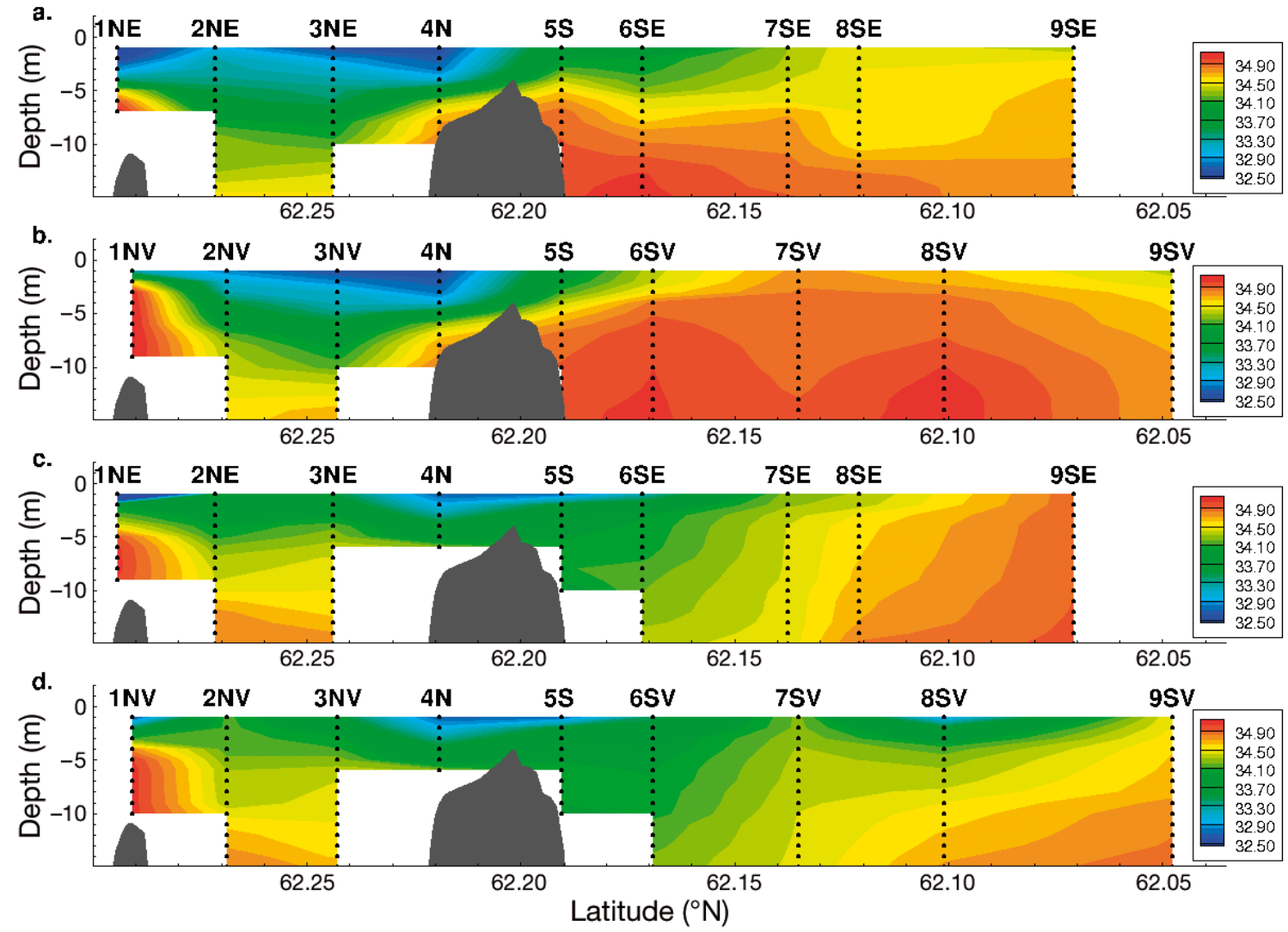

Fig. 4. Salinity in the upper $15 \mathrm{~m}$ of the water column during the spatial surveys in (a,b) November 2013 and (c,d) February 2014. Grey area: bottom depth at the 2 shallow sills separating the northern basin from the open ocean (left grey area), and the southern from the northern basin (middle grey area). Stations are as in Fig. 1 
Table 1. Lepeophtheirus salmonis and Caligus elongatus. Densities of nauplii and copepodids in the top meter of the water column on November 18, 2013 and February 26, 2014. N, S, E, W: stations located in the northern and southern basins, and in the eastern and western shores, respectively

\begin{tabular}{|c|c|c|c|c|c|c|c|c|}
\hline \multirow[t]{2}{*}{ Station } & \multicolumn{2}{|c|}{$\begin{array}{l}\text { L. salmonis nauplii } \\
\text { (ind. } \mathrm{m}^{-3} \text { ) }\end{array}$} & \multicolumn{2}{|c|}{$\begin{array}{l}\text { L. salmonis copepodids } \\
\text { (ind. } \mathrm{m}^{-3} \text { ) }\end{array}$} & \multicolumn{2}{|c|}{$\begin{array}{l}\text { C. elongatus nauplii } \\
\text { (ind. } \mathrm{m}^{-3} \text { ) }\end{array}$} & \multicolumn{2}{|c|}{$\begin{array}{l}\text { C. elongatus copepodids } \\
\text { (ind. } \mathrm{m}^{-3} \text { ) }\end{array}$} \\
\hline & Nov. & Feb. & Nov. & Feb. & Nov. & Feb. & Nov. & Feb. \\
\hline $1 \mathrm{NW}$ & 0 & 0 & 0 & 0 & 0.02 & 0 & 0.02 & 0.10 \\
\hline $1 \mathrm{NE}$ & 0 & 0 & 0 & 0 & 0.03 & 0 & 0.05 & 0 \\
\hline $2 \mathrm{NW}$ & 0 & 0 & 0.02 & 0 & 0 & 0.05 & 0.05 & 0.03 \\
\hline $2 \mathrm{NE}$ & 0 & 0 & 0 & 0.03 & 0 & 0 & 0.08 & 0.28 \\
\hline $3 \mathrm{NW}$ & 0 & 0 & 0 & 0 & 0.05 & 0 & 0.08 & 0.05 \\
\hline $3 \mathrm{NE}$ & 0 & 0 & 0.06 & 0.02 & 0 & 0 & 0.09 & 0.10 \\
\hline $4 \mathrm{~N}$ & 0 & 0 & 0.06 & 0.06 & 0.02 & 0.02 & 0.21 & 0.13 \\
\hline $5 \mathrm{~S}$ & 0 & 0 & 0.03 & 0 & 0.24 & 0 & 0.3 & 0 \\
\hline $6 \mathrm{SW}$ & 0 & 0 & 0 & 0.10 & 0.03 & 0 & 0.11 & 0.03 \\
\hline $6 \mathrm{SE}$ & 0 & 0 & 0.03 & 0.21 & 0 & 0 & 0.15 & 0 \\
\hline $7 \mathrm{SW}$ & 0 & 0 & 0 & 0.13 & 0.08 & 0 & 0.05 & 0.03 \\
\hline $7 \mathrm{SE}$ & 0 & 0 & 0 & 0 & 0 & 0 & 0.20 & 0.05 \\
\hline 8SW & 0 & 0 & 0 & 0.17 & 0 & 0 & 0.02 & 0.02 \\
\hline $8 \mathrm{SE}$ & 0 & 0 & 0.05 & 0 & 0 & 0.03 & 0.02 & 0 \\
\hline 9SW & 0 & 0 & 0 & 0.04 & 0.02 & 0 & 0.34 & 0.04 \\
\hline 9SE & 0 & 0 & 0.03 & 0 & 0 & 0 & 0.13 & 0.03 \\
\hline
\end{tabular}

salmonis copepodids was 0.02 cop. $\mathrm{m}^{-3}$ both in the northern and southern basins.

There were only minor changes in the L. salmonis abundance in the northern basin between the November and February sampling periods, but the average abundance had increased to $0.07 \mathrm{cop} . \mathrm{m}^{-3}$ in February in the southern basin. The copepodids were mostly found on the west side of the sound although the fish farms were located on the east side (Table 1).

The pooled number of $L$. salmonis in the plankton samples from the east and west sides of Sundalagið differed significantly between the 2 surveys with different hydrodynamic conditions $\chi^{2}=4.77, \mathrm{df}=1$, $\mathrm{p}<0.05)$. Such statistical difference was not observed in Caligus elongatus $\left(\chi^{2}=0.009, \mathrm{df}=1, \mathrm{p}=0.92\right)$.

Caligus elongatus were highly abundant in November, with copepodids being present in all stations (Table 1 ). The average density of $C$. elongatus copepodids was 0.08 cop. $\mathrm{m}^{-3}$ in the northern basin, and almost twice as high in the southern basin. It was also in the southern basin, at Stn 9SW, where the highest density $\left(0.34\right.$ cop. $\left.\mathrm{m}^{-3}\right)$ was observed. The average abundance showed a small increase to $0.10 \mathrm{cop} . \mathrm{m}^{-3}$ in February in the northern basin, but decreased from 0.15 cop. $\mathrm{m}^{-3}$ in November to 0.02 cop. $\mathrm{m}^{-3}$ in February in the southern basin. There were substantially fewer nauplii than copepodids (ratio 1:6.5) during the 2 regional samplings and all of these were C. elongatus (Table 1).
Temporal changes

Throughout the study, the abundance of L. salmonis was below 0.2 ind. $\mathrm{m}^{-3}$ at Stns $4 \mathrm{~N}$ and $5 \mathrm{~S}$. Temporal changes were not that evident at Stn $5 \mathrm{~S}$, but abundance was higher during spring than in winter at Stn $4 \mathrm{~N}$ (Fig. 5). At Stn 3NE, which was $~ 600 \mathrm{~m}$ downstream of a fish farm, $L$. salmonis was much more abundant. Clear seasonal trends were observed at this station, with low numbers until early March, followed by a peak in abundance of 3.2 ind. $\mathrm{m}^{-3}$ in late March, and a quick subsequent decline (Fig. 5). No planktonic sea lice were observed at Stn 3NE from mid-May to the end of the study. At the other 2 stations, sea lice were also scarce towards the end of the study. By the last field trip, all the farms in Sundalagio lay fallow and no planktonic stages of $L$. salmonis were found.

From the onset of the investigation to late February, C. elongatus was the dominant sea louse species at all stations (Fig. 5). The highest density was observed in mid-February at Stn $5 \mathrm{~S}\left(0.96\right.$ ind. $\left.\mathrm{m}^{-3}\right)$. During March, the species composition started to change, and only one planktonic C. elongatus was observed in the samples from April to the end of the study (Fig. 5).

During winter, when $C$. elongatus was the most abundant sea louse species, copepodids dominated the planktonic stages; the shift towards higher abundance of $L$. salmonis in the succeeding months was largely due to nauplius stages (Fig. 6). The dominance of nauplii was especially pronounced at 


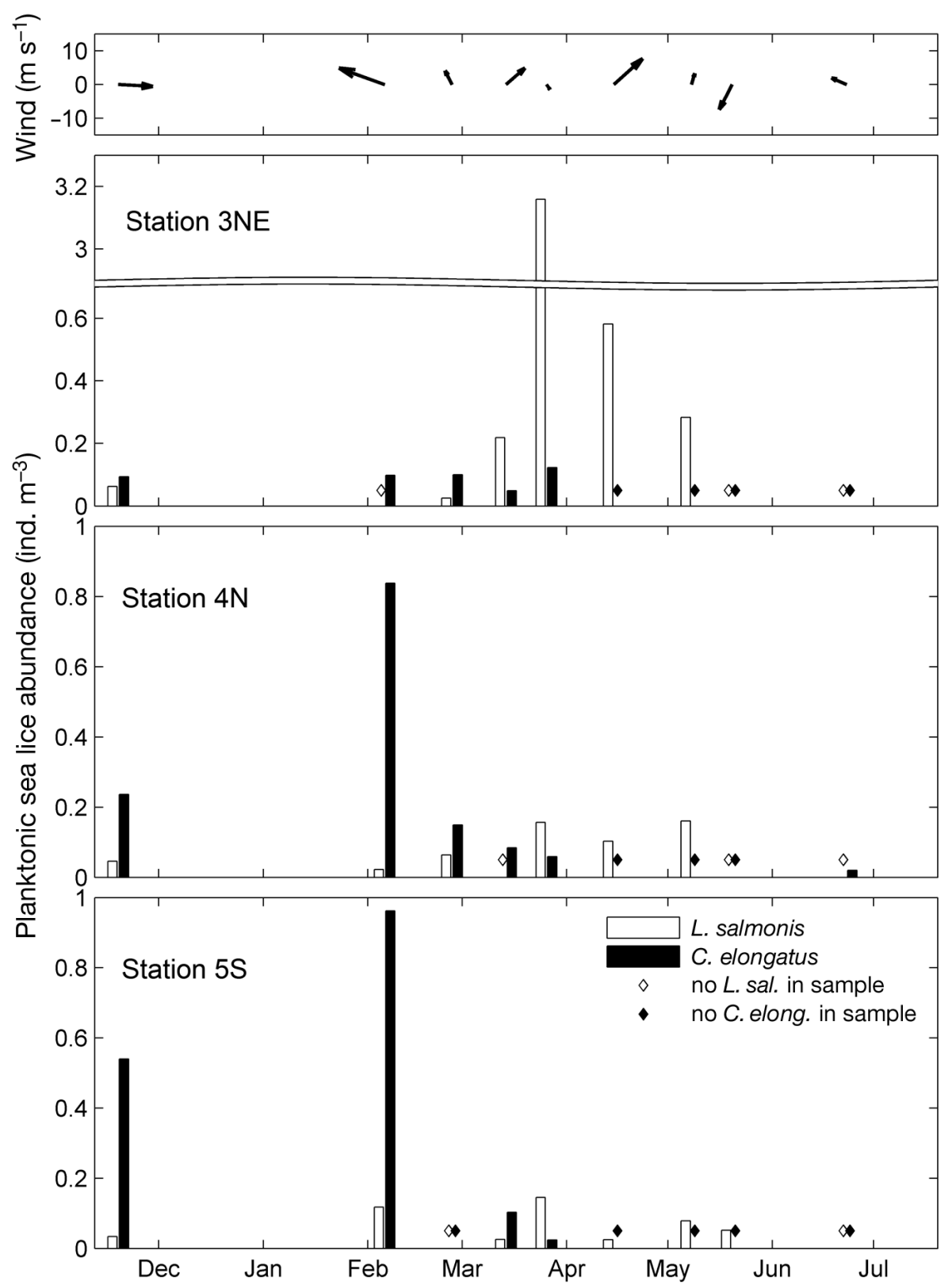

Fig. 5. Lepeophtheirus salmonis (white) and Caligus elongatus (black). Time series of abundance (nauplii and copepodids) in the top meter of the water column at stations 3NE, $4 \mathrm{~N}$ and 5S. Bars: densities, diamonds: samples with no sea lice. Arrows in uppermost panel: wind direction and speed averaged over $12 \mathrm{~h}$ prior to the field investigations

Stn 3NE, where the nauplii to copepodid ratio ranged between 4 and 8 in March and April. At Stn $4 \mathrm{~N}$, the ratio ranged between 0.14 and 4 in the same period.

The abundance of gravid C. elongatus on fish farmed in Sundalagið changed with season, with low abundances during the summer months (Fig. 7). In the southern basin, the initial increase in abundance typically occurred in September and peaked from November to January. In the northern basin, abundance increased later, with peak abundance occurring in February (Fig. 7).

\section{Reliability in identification}

Lepeophtheirus salmonis and C. elongatus are the most abundant sea lice on farmed salmon in the Faroe Islands. Of a total of 520 chalimi stage individuals sampled randomly from farmed Atlantic salmon, 147 and 366 were identified as L. salmonis and $C$. elongatus, respectively, using duplex real-time PCR assay. Thus, only 7 sea lice were unidentified.

The real-time PCR results showed that $C$. elongatus and L. salmonis contributed largely to the plank- 

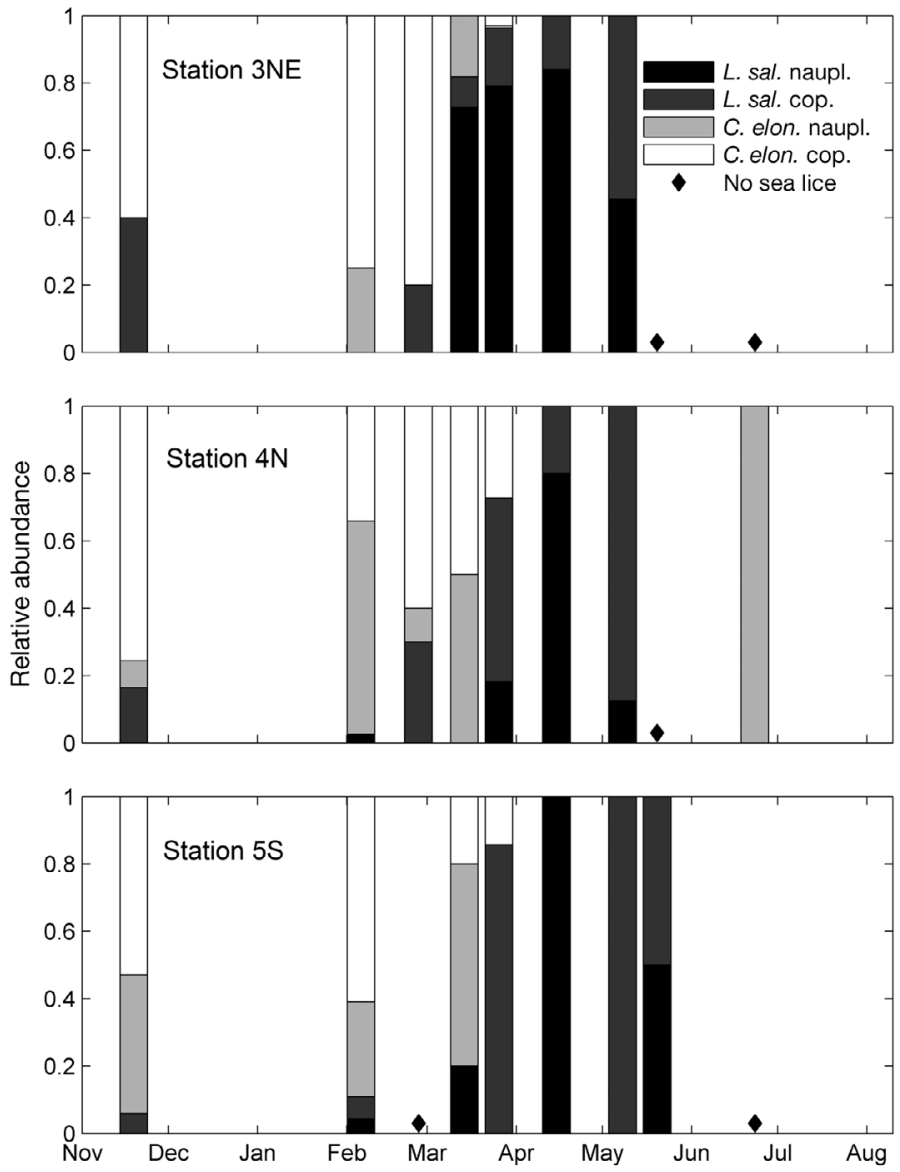

Fig. 6. Lepeophtheirus salmonis and Caligus elongatus. Relative abundance of nauplii and copepodids in the top meter of the water column from November 2013 to June 2014 at the 3 time series stations

ton samples, as all the 35 nauplii identified by the method were either of the 2 species. Further, the results confirmed the high reliability of the identification of nauplii through their pigmentation.

In a plankton sample containing 21 nauplii identified as L. salmonis through their pigmentation, realtime PCR was run on 10 nauplii and the identity was confirmed. In a second sample, with dominance of $C$. elongatus $(\mathrm{n}=49)$, a few L. salmonis $(\mathrm{n}=3)$ and a high number of unidentified nauplii $(n=5)$, the assay was run on 23 of the nauplii. The assay identified one nauplius as $L$. salmonis and the remaining 22 as $C$. elongatus. Thus, the frequency of $C$. elongatus was high using both real-time PCR and stereomicroscopic investigation of the total sample. Approximately $96 \%$ of the nauplii tested by real-time PCR were C. elongatus, while their occurrence in the total sample was 85 to $95 \%$ depending on the identity of nauplii with faded pigmentation.

\section{DISCUSSION}

This study provides the first insight into the spatial and temporal distribution of planktonic sea lice in the Faroe Islands. The density of planktonic sea lice was within the range found in other regions (Costelloe et al. 1998, Penston et al. 2004, 2008, 2011, Penston \& Davies 2009, Molinet et al. 2011, Morton et al. 2011). However, the reported densities are highly variable depending largely on distance to shore and to fish farms. Lepeophtheirus salmonis nauplii are most commonly found near fish farms, with the nauplii to copepodid ratio decreasing with distance to farms (Costelloe et al. 1996, Penston et al. 2004, 2008, Morton et al. 2011). This was also the case in the present study (Fig. 6).

\section{Spatial distribution}

The 2 spatial surveys showed pronounced influence of winds on the hydrography of the southern basin in Sundalagio. In the $12 \mathrm{~h}$ prior to the sampling in November, winds came from the west (Fig. 3), and the less saline surface water was pressed towards the eastern shore (Fig. 4). At that time, L. salmonis were only found in the eastern shore (Table 1). In February, winds pushed the surface waters westwards, and L. salmonis were again found in the less saline water along the western shore.

The local weather changes quite rapidly (Gaard et al. 2011), and the representativeness of the physical conditions during the 2 spatial surveys as general situations in the local area might be limited. Nevertheless, this study provides a direct observation of the influence of winds on the hydrography and distribution of planktonic L. salmonis; the reversed distribution of sea lice in Sundalagið during the 2 different dates could be explained by the wind and hydrographic conditions at the time of the field studies. This highlights the importance of applying hydrodynamic models that include wind patterns when modelling infection pressure of L. salmonis, as also emphasized by Salama \& Rabe (2013) and Johnsen et al. (2014). Such models predict the distribution of planktonic sea lice to be patchy and that they tend to accumulate in areas close to the shore (Amundrud \& Murray 2009, Salama \& Rabe 2013, Asplin et al. 2014). This is also the general observation in field studies of $L$. salmonis copepodids (McKibben \& Hay 2004, Penston et al. 2004, Penston \& Davies 2009).

The spatial distribution of Caligus elongatus copepodids did not reflect the hydrographic conditions in 


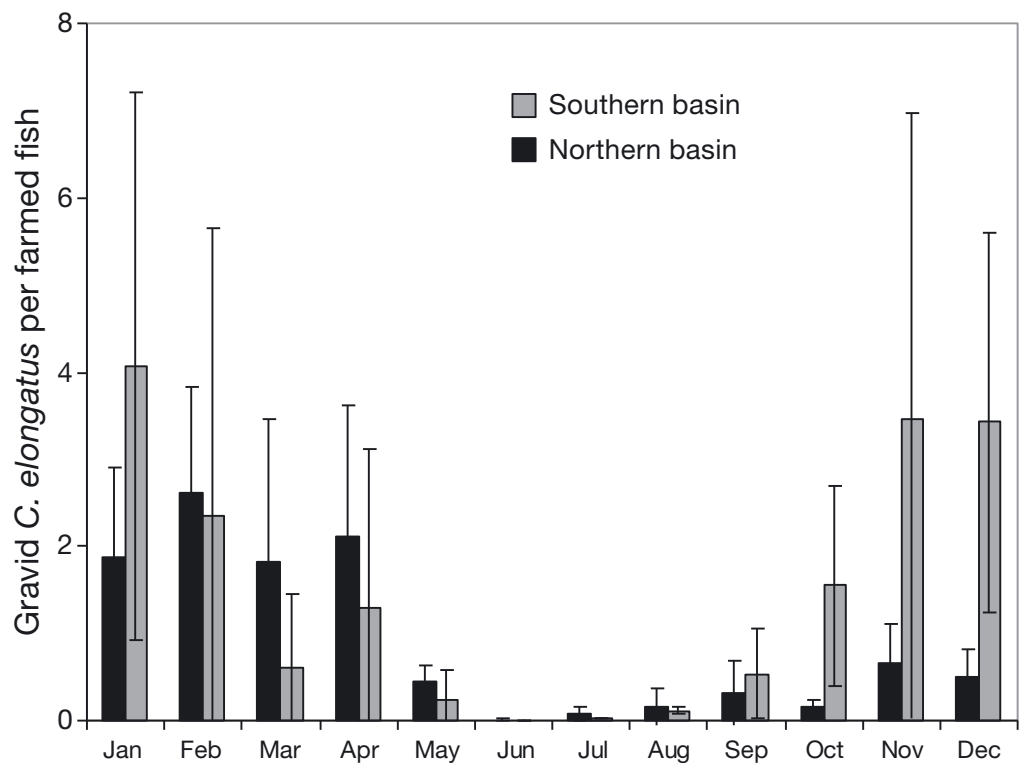

Fig. 7. Monthly averaged abundance of gravid Caligus elongatus during 2 farming cycles (2010-2014) at a salmon farm in the southern basin in Sundalagið (grey bars) and a farm in the northern basin (black bars). Error bars: $\mathrm{SE}$ between years

the upper water masses as clearly as the spatial distribution of L. salmonis (Table 1). This might be due to different vertical migration strategies between the 2 species. Lepeophtheirus salmonis copepodids are most abundant in the top $4 \mathrm{~m}$ of the water column (Hevrøy et al. 2003, Costello 2006), and although they show diel vertical migration, they only migrate small distances and still swim high in the water column at night (Heuch et al. 1995). Thus, they are continuously dispersed with surface currents that are influenced by winds.

Knowledge on the vertical distribution and migration of $C$. elongatus copepodids is scarce, as most studies focus on L. salmonis. However, given its wide range of hosts, it may not necessarily be beneficial for C. elongatus copepodids to constantly seek the upper few meters of the water column.

A study on C. elongatus infesting haddock suggests that larvae are distributed in mid water, intercepting haddock that swim through this zone (Costello 1993). Moreover, copepodids of a related species (Caligus rogercresseyi) have been found to be common below the pycnocline, despite being more abundant in surface waters, especially during the day (Molinet et al. 2011). If the vertical migration of $C$. elongatus exceeds the depth of stratification, their abundance at the top of the water column might be less affected by the actual wind situation compared to L. salmonis, given the shorter period of drifting with the surface currents.

\section{Temporal changes}

Other studies have found correlations between the abundance of gravid $L$. salmonis on farmed fish and copepodid abundance (Penston \& Davies 2009, Pert et al. 2014). In this study, planktonic $L$. salmonis were completely absent in the samples when the region lay fallow, and they were scarce during earlier field trips when the number of farmed hosts was low (Fig. 5).

At the last 2 field surveys, the wind direction might have had an influence on the absence of sea lice at Stn 3NE, as the wind may have directed the water masses from the closest fish farm southwards in late May and away from the shore in June (Fig. 5). On the other hand, the 2 spatial surveys showed small influence from winds in the northern basin, where tidal currents are stronger than in the southern basin (Fig. 4). Stn $4 \mathrm{~N}$ was sampled across the sound covering both shores, and should be less affected by the actual wind situation. L. salmonis was absent in the last 2 time series samples at Stn $4 \mathrm{~N}$.

The peak in L. salmonis abundance (3.2 ind. $\mathrm{m}^{-3}$, of which $80 \%$ were nauplii) was observed in late March at Stn 3NE (Figs. $5 \& 6$ ). The field sampling took place during a bath treatment for sea lice at the nearest fish farm. This was part of the annual national coordinated delousing, which took place from midMarch to mid-April. Penston et al. (2004) observed pulses of larvae in Loch Shieldaig and speculated that sea lice treatments could trigger release of nauplii from egg strings of farmed lice. They further stated that the treatment just pre-empted a natural release of larvae. In Sundalagið, the numbers of planktonic $L$. salmonis had started to increase prior to the delousing activity, and remained elevated until mid-May (Fig. 5). In addition, the nature of egg production by females implies that it is highly unlikely for females to respond in the limited period of bath treatments (Pike \& Wadsworth 1999). However, bath treatments might have caused pre-eclosion of nauplii, which could possibly be triggered by changes in osmotic pressure of the fluid within the egg membrane (Gravil 1996, Pike \& Wadsworth 1999).

Despite the decreasing number of farmed hosts in Sundalagið, there was a pronounced increase in the abundance of planktonic L. salmonis, most of which were nauplii, in March (Fig. 6). The increase co- 
occurred with the initial warming of the sea water surface (Fig. 2b). The appearance of L. salmonis nauplii in the surface water samples in spring agreed with one of the model simulations by Johnsen et al. (2014), which was based on the assumption that nauplii might have the ability to sense temperature and vertically seek warm waters. This would increase their chance of surviving to the copepodid stage, as survival increases with decreasing duration of the nauplii stage. Conversely, the copepodids were not modelled to seek warm waters, since swimming high in the water column increases the chances of intercepting suitable hosts (Heuch et al. 1995, Pike \& Wadsworth 1999, Costello 2006).

During winter, when the surface water was colder than the deeper water masses (Fig. 2), L. salmonis nauplii were present in only $9 \%$ of the 44 samples, while copepodid prevalence was $47 \%$. In the 15 samples where the surface water was vertically the warmest, the prevalence of nauplii increased significantly to $53 \%\left(\chi^{2}=10.9, \mathrm{df}=1, \mathrm{p}<0.001\right)$. Copepodid prevalence increased to $60 \%$, but this was not significantly different from the winter situation $\left(\chi^{2}=2.64\right.$, $\mathrm{df}=1, \mathrm{p}=0.103)$. Thus, this study provides field evidence that $L$. salmonis nauplii possibly seek the highest achievable temperature within the water column, and lends support to the assumption of nauplii ability to sense temperature in the model runs of Johnsen et al. (2014).

There was a pronounced seasonal change in $C$. elongatus abundance, from being the dominant planktonic sea louse species during winter to being virtually absent during summer (Fig. 5). The same seasonal changes were also evident in C. elongatus on fish farmed in Sundalagið (Fig. 7). This pattern is opposite that which would be expected if productivity were temperature dependent. The pattern is most likely connected to the migration of some unknown fish species, as was also observed in Norway and Scotland (Revie et al. 2002, Øines et al. 2006). However, the timing of infestation in Sundalagio is unlike that in both Scotland and Norway, where infestations occur mainly in summer and early autumn (Revie et al. 2002, Øines et al. 2006).

Despite the limited number of studies on fish abundance in Faroese nearshore waters (Bertelsen 1942, Joensen et al. 2005), there is no doubt that a wide range of $C$. elongatus host species are present in the fjords and straits and even aggregate around fish farms (Dempster et al. 2009). When comparing the population dynamics and migration patterns of the most common fish species in Faroese waters, i.e. mackerel (Scomber scombrus), herring (Clupea harengus), cod (Gadus morhua), haddock (Melanogrammus aeglefinus) and saithe (Pollachius virens), to the population dynamics of $C$. elongatus on farmed salmon, only saithe seems to provide a promising explanation.

Saithe commonly aggregates around fish cages, with the 0 -yr group even moving into net pens. Although part of the saithe population is present in the sublittoral zone year round, migration does occur. One-year-old saithe apparently move offshore during summer, as judged by low numbers caught in beach seines (Bertelsen 1942). However, some of the older saithe (1 to 2 yr) re-enter the coastal areas during autumn and winter (Bertelsen 1942, Højgaard 1997). It is possible that migrating saithe carry $C$. elongatus when they enter coastal areas, which might explain the seasonality observed in $C$. elongatus abundance in this study. However, there are many more uninvestigated fish species in Faroese coastal waters, most of which might influence $C$. elongatus abundance on farmed fish.

The ecological consequences of $C$. elongatus facilitated interactions between farmed and wild fish are unknown, and not easily established. In contrast to L. salmonis, research on C. elongatus is highly sporadic. The latter species should receive much more attention as it might play an important, although yet unknown role in the coastal environment.

In conclusion, this study investigated planktonic stages of sea lice in a region where both $L$. salmonis and C. elongatus were abundant, providing insights into the 2 sea lice species simultaneously. The direct observation of the influence of winds on the distribution of $L$. salmonis highlights the importance of including wind patterns in hydrodynamic modelling of the infestation pressure of the species. However, C. elongatus was not equally influenced by winds. The vertical migration pattern of planktonic C. elongatus is unknown, and it is possible that this pattern could explain the lack of wind influence on the species. Seasonal abundance also differed between the 2 species. C. elongatus was highly abundant during winter, but was virtually absent from April to June when the study terminated. L. salmonis nauplii abundance increased substantially during early spring when the warmest water was located at the surface as opposed to deeper in the water column. The sudden appearance of nauplii in the warmer surface water could indicate that they seek the highest possible temperature vertically, as this would shorten their development time to the infectious copepodid stage, thereby reducing predation mortality. 
Acknowledgements. We thank P/F Marine Harvest Faroes for providing sea lice data and information on their farming activity in Sundalagið, P/F Bakkafrost for information on their farming cycle in Sundalagið, Faroe Marine Research Institute for equipment and laboratory space, Ebba Mortensen for processing CTD data, Terji T. Magnussen and Esbern Patursson for assistance in the field, and Ann Siri Borg Hentze and Kristín Baldvinsdóttir for assistance in the laboratory. The research was funded by the Faroese Research Council, Faroese Food- and Veterinary Authority and the Aquaculture Research Station of the Faroes.

\section{LITERATURE CITED}

Amundrud TL, Murray AG (2009) Modelling sea lice dispersion under varying environmental forcing in a Scottish sea loch. J Fish Dis 32:27-44

- Asplin L, Johnsen IA, Sandvik AD, Albretsen J, Sundfjord V, Aure J, Boxaspen K (2014) Dispersion of salmon lice in the Hardangerfjord. Mar Biol Res 10:216-225

> Beamish R, Wade J, Pennell W, Gordon E and others (2009) A large, natural infection of sea lice on juvenile Pacific salmon in the Gulf Islands area of British Columbia, Canada. Aquaculture 297:31-37

Bertelsen E (1942) Contributions to the biology of the coalfish (Gadus virens L.) in Faroe waters. Medd Kom Dan Fisk Havunders Fisk 11:3-69

Boxaspen K (2006) A review of the biology and genetics of sea lice. ICES J Mar Sci 63:1304-1316

Bricknell IR, Dalesman SJ, O'Shea B, Pert CC, Luntz AJM (2006) Effect of environmental salinity on sea lice Lepeophtheirus salmonis settlement success. Dis Aquat Org 71:201-212

Costello MJ (1993) Review of methods to control sea-lice (Caligidae, Crustacea) infestations on salmon farms. In: Boxshall GA, Defaye D (eds) Pathogens of wild and farmed fish: sea lice. Ellis Horwood, Chichester, p 219-252

Costello MJ (2006) Ecology of sea lice parasitic on farmed and wild fish. Trends Parasitol 22:475-483

Costelloe M, Costelloe J, Roche N (1996) Planktonic dispersion of larval salmon-lice, Lepeophtheirus salmonis, associated with cultured salmon, Salmo salar, in western Ireland. J Mar Biol Assoc UK 76:141-149

> Costelloe M, Costelloe J, Coghlan N, O'Donohoe G, O'Connor B (1998) Distribution of the larval stages of Lepeophtheirus salmonis in three bays on the west coast of Ireland. ICES J Mar Sci 55:181-187

Danielsen E (2013) Identification of the free swimming larval stages of Caligus elongatus and Lepeophtheirus salmonis. Fiskaaling rit 2015-5, Technical Report, Fiskaaling, Faroe Islands

Dempster T, Uglem I, Sanchez-Jerez P, Fernandez-Jover D, Bayle-Sempere J, Nilsen R, Bjørn PA (2009) Coastal salmon farms attract large and persistent aggregations of wild fish: an ecosystem effect. Mar Ecol Prog Ser 385:1-14

Fowler J, Cohen L, Jarvis P (1998) Practical statistics for field biology, 2nd edn. John Wiley \& Sons, Chichester

Gaard E, á Norði G, Simonsen K (2011) Environmental effects on phytoplankton production in a Northeast Atlantic fjord, Faroe Islands. J Plankton Res 33:947-959

Gravil HR (1996) Studies on the biology and ecology of the free swimming larval stages of Lepeophtheirus salmonis (Krøyer, 1838) and Caligus elongatus Nordmann, 1832
(Copepoda: Caligidae). PhD dissertation, University of Stirling

Hamre LA, Eichner C, Caipang CMA, Dalvin ST and others (2013) The salmon louse Lepeophtheirus salmonis (Copepoda: Caligidae) life cycle has only two chalimus stages. PLoS ONE 8:e73539

> Heuch PA, Parsons A, Boxaspen K (1995) Diel vertical migration: a possible host-finding mechanism in salmon louse (Lepeophtheirus salmonis) copepodids? Can J Fish Aquat Sci 52:681-689

$>$ Heuch PA, Øines Ø, Knutsen JA, Schram TA (2007) Infection of wild fishes by the parasitic copepod Caligus elongatus on the south east coast of Norway. Dis Aquat Org 77: $149-158$

> Hevrøy EM, Boxaspen K, Oppedal F, Taranger GL, Holm JC (2003) The effect of artificial light treatment and depth on the infestation of the sea louse Lepeophtheirus salmonis on Atlantic salmon (Salmo salar L.) culture. Aquaculture 220:1-14

Højgaard DP (1997) Seasonal changes in the infection of young saithe, Pollachius virens, with Anisakis simplex and other helminths. Fróðskaparrit 45:57-68

Joensen JS, Steingrund P, Henriksen A, Mouritsen R (2005) Migration of cod (Gadus morhua): tagging experiments at the Faroes 1952-1965. Fróðskaparrit 53:100-135

Johnsen IA, Fiksen Ø, Sandvik AD, Asplin L (2014) Vertical salmon lice behaviour as a response to environmental conditions and its influence on regional dispersion in a fjord system. Aquacult Environ Interact 5:127-141

Johnson SC, Albright LJ (1991) Development, growth, and survival of Lepeophtheirus salmonis (Copepoda: Caligidae) under laboratory conditions. J Mar Biol Assoc UK 71:425-436

Kabata Z (1979) Parasitic Copepoda of British fishes. The Ray Society, London

MacKenzie K, Morrison JA (1989) An unusually heavy infestation of herring (Clupea harengus L.) with the parasitic copepod Caligus elongatus Nordmann, 1832. Bull Eur Assoc Fish Pathol 9:12-13

McBeath AJA, Penston MJ, Snow M, Cook PF, Bricknell IR, Cunningham CO (2006) Development and application of real-time PCR for specific detection of Lepeophtheirus salmonis and Caligus elongatus larvae in Scottish plankton samples. Dis Aquat Org 73:141-150

> McKenzie E, Gettinby G, McCart K, Revie CW (2004) Timeseries models of sea lice Caligus elongatus (Nordmann) abundance on Atlantic salmon Salmo salar L. in Loch Sunart, Scotland. Aquacult Res 35:764-772

McKibben MA, Hay DW (2004) Distributions of planktonic sea lice larvae Lepeophtheirus salmonis in the inter-tidal zone in Loch Torridon, Western Scotland in relation to salmon farm production cycles. Aquacult Res 35:742-750

> Molinet C, Cáceres M, Gonzalez MT, Carvajal J and others (2011) Population dynamics of early stages of Caligus rogercresseyi in an embayment used for intensive salmon farms in Chilean inland seas. Aquaculture 312: 62-71

> Mordue Luntz AJ, Birkett MA (2009) A review of host finding behavior in the parasitic sea louse, Lepeophtheirus salmonis (Caligidae: Copepoda). J Fish Dis 32:3-13

> Morton A, Routledge R, Krkošek M (2008) Sea louse infestation in wild juvenile salmon and Pacific herring associated with fish farms off the east-central coast of Vancouver Island, British Columbia. N Am J Fish Manag 28: $523-532$ 
Morton A, Routledge R, McConnel A, Krkošek M (2011) Sea lice dispersion and salmon survival in relation to salmon farm activity in the Broughton Archipelago. ICES J Mar Sci 68:144-156

Neilson JD, Perry RI, Scott JS, Valerio P (1987) Interactions of caligid ectoparasites and juvenile gadids on Georges Bank. Mar Ecol Prog Ser 39:221-232

Øines Ø, Simonsen JH, Knutsen JA, Heuch PA (2006) Host preference of adult Caligus elongatus Nordmann in the laboratory and its implications for Atlantic cod aquaculture. J Fish Dis 29:167-174

Penston MJ, Davies IM (2009) An assessment of salmon farms and wild salmonids as sources of Lepeophtheirus salmonis (Krøyer) copepodids in the water column in Loch Torridon, Scotland. J Fish Dis 32:75-88

Penston MJ, McKibben MA, Gillibrandt PA (2004) Observations on open-water densities of sea lice larvae in Loch Shieldaig, Western Scotland. Aquacult Res 35:793-805

Penston MJ, Millar CP, Zuur A, Davies IM (2008) Spatial and temporal distribution of Lepeophtheirus salmonis (Krøyer) larvae in a sea loch containing Atlantic salmon, Salmo salar L., farms on the north-west coast of Scotland. J Fish Dis 31:361-371

Penston MJ, McBeath AJA, Millar CP (2011) Densities of planktonic Lepeophtheirus salmonis before and after an Atlantic salmon farm relocation. Aquacult Environ Interact 1:225-232

Pert CC, Fryer RJ, Cook P, Kilburn R and others (2014) Using sentinel cages to estimate infestation pressure on

Editorial responsibility: Bengt Finstad,

Trondheim, Norway salmonids from sea lice in Loch Shieldaig, Scotland. Aquacult Environ Interact 5:49-59

Piasecki W, MacKinnon BM (1995) Life cycle of a sea louse, Caligus elongatus von Nordmann, 1832 (Copepoda, Siphonostomatoida, Caligidae). Can J Zool 73:74-82

Pike AW, Wadsworth SL (1999) Sealice on salmonids: their biology and control. Adv Parasitol 44:233-337

Pike AW, Mordue AJ, Ritchie G (1993) The development of Caligus elongatus Nordmann from hatching to copepodid in relation to temperature. In: Boxshall GA, Defaye D (eds) Pathogens of wild and farmed fish: sea lice. Taylor and Francis, Chichester, p 51-60

Revie CW, Gettinby G, Treasurer JW, Rae GH (2002) The epidemiology of the sea lice, Caligus elongatus Nordmann, in marine aquaculture of Atlantic salmon, Salmo salar L., in Scotland. J Fish Dis 25:391-399

Salama NKG, Rabe B (2013) Developing models for investigating the environmental transmission of diseasecausing agents within open-cage salmon aquaculture. Aquacult Environ Interact 4:91-115

Schram TA (2004) Practical identification of pelagic sea lice larvae. J Mar Biol Assoc UK 84:103-110

Simonsen K, Niclasen B (2011) On the energy potential in the tidal streams on the Faroe Shelf. NVDRit 2011:01, Technical Report, University of the Faroe Islands

Stien A, Bjørn PA, Heuch PA, Elston DA (2005) Population dynamics of salmon lice Lepeophtheirus salmonis on Atlantic salmon and sea trout. Mar Ecol Prog Ser 290: 263-275

Submitted: December 3, 2014; Accepted: April 14, 2015 Proofs received from author(s): May 19, 2015 